\title{
ANALISIS KOMUNIKASI DAN LINGKUNGAN KERJA TERHADAP KEPUASAN KERJA PEGAWAI PADA DINAS TANAMAN PANGAN HORTIKULTURA DAN PETERNAKAN KABUPATEN WAY KANAN.
}

\author{
Nuraeni $^{(1)}$, Muhammad Sahid $^{(2)}$ \\ Universitas Sang Bumi Ruwa Jurai \\ email : nuraeniharyo@gmai.com,muhsahid2021@gmail.com
}

\begin{abstract}
Abstrak. Penelitian ini bertujuan untuk menganalis komunikasi dan lingkungan kerja terhadap kepuasaan kerja pegawai. Penelitian ini dilakukan pada Kantor Dinas Tanaman Pangan Hortikultura Dan Peternakan Kabupaten Way Kanan. Jenis penelitian ini menggunakan penelitian kuantitatif deskriptif. Penelitian menggunakan 56 responden dan menggunakan jenis data primer dan skunder. Teknik pengumpulan data pada penelitian ini menggunakan observasi kuisioner dan telaah kepustakaan. Berdasarkan penelitian yang dilakukan menunjukan bahwa Komunikasi dan lingkungan kerja secara bersama-sama memiliki pengaruh terhadap Kepuasan Kerja Pegawai pada Dinas Tanaman Pangan Hortikultura Dan Peternakan Kabupaten Way Kanan, dibuktikan dengan hipotesis yang menyatakan bahwa komunikasi dan lingkungan kerja berpengaruh terhadap kepuasan kerja pegawai sebesar $67,1 \%$ oleh komunikasi dan lingkungan kerja secara bersama-sama, sementara sisanya sebesar 32,9\% dipengaruhi oleh faktor yang lainnya yang tidak ada dalam penelitian ini.
\end{abstract}

Kata Kunci : Komunikasi, Lingkungan kerja, Kepuasaan kerja

Abstract. This study aims to see communication and work environment on employee job satisfaction. This research was conducted at the Office of the Food Crops Horticulture and Animal Husbandry Way Kanan Regency. This type of research uses descriptive quantitative research. This research uses primary and secondary data. The data technique used in the study was questionnaire observation and literature review. Based on the research conducted, it shows that communication and work environment together have an influence on Employee Job Satisfaction at the Food Crops and Animal Husbandry Office of Way Kanan Regency, evidenced by a statement stating that communication and work environment affect employee job satisfaction by $67.1 \%$. by communication and work environment together, while the remaining $32.9 \%$ of the factors that do not exist in this study.

Keywords: Communication, work environment, job satisfaction

\section{PENDAHULUAN}

Saat ini peranan sumber daya manusia pada dunia kerja, baik swasta ataupun pemerintah sangat penting. Sumber daya manusia yang baik akan berdampak luas kepada aktivitas dan jalannya suatu institusi baik swasta atau negeri sehingga akan memudahkan tercapainya efektivitas dan efisiensi yang tinggi pada kinerja organisasi tersebut. Tingkat kemajuan ilmu pengetahuan dan teknologi, yang akhir-akhir ini berkembang sangat pesat, sangat membantu manusia dalam meningkatkan kinerjanya. Dengan mencermati keadaan saat ini dimana Kinerja mendapat soroton tajam di dalam organisasi, maka sebagai pekerja tidak boleh lamban dalam merespon dinamika kepentingan masyarakat. Pekerja yang lamban dalam merespon perubahan, maka kinerja seolah-olah berjalan ditempat, hanya sebagai suatu rutinitas tanpa target atau 
outcome yang jelas.

Setiap organisasi baik swasta maupun pemerintah dalam rangka mencapai tujuannya akan dipengaruhi oleh beberapa faktor. Faktor-faktor tersebut perlu diarahkan secara efektif dan efesien melalui manajemen yang baik. Selain sumber-sumber alam dan modal, faktor penting lainnya adalah sumber daya manusia. Melalui kegiatan-kegiatan yang dilakukan oleh manusia maka organisasi dapat mencapai tujuannya.

Pengelolaan sumber daya manusia dalam arti peningkatan kepuasan kerja pegawai disatuan kerja pemerintah daerah merupakan unsur terpenting selain adanya dukungan sumber dana sarana dan prasarana. Persoalan itu mengacu pendapat Sondang $\mathrm{P}$ Siagian (Siagian 2014) yang menyatakan "manusia merupakan unsur yang terpenting selain unsur lain yang dimiliki oleh suatu organisasi seperti uang, materi, mesinmesin dan metode kerja, waktu dan kekayaan lainnyayang dapat memberikan manfaat bagi organisasi, jika manusia didalam organisasi itu merupakan daya pembangun dan bukan perusak bagi organisasi" Pendapat itu memperjelas manusia merupakanunsur sentral dalam suatu organisasi karena manusia merupakan perencana sekaligus pelaku aktif dalam kegiatan organisasi tersebut. Berarti pengembangan sumber daya manusia harus selalu dirtingkatkan, sebab mereka memiliki kedudukan yang sangat penting dan strategis didalam suatu organisasi untuk mencapai tujuan.

Suatu organisasi (Satuan Kerja Perangkat Daerah) dibangun dan dikelola dengan komunikasi, artinya ketika proses komunikasi antarkomponen dari unit-unit kerja tersebut dapat diselenggarakan secara harmonis, maka organisasi tersebut semakin kokoh dan kinerja pegawai akan meningkat. Sumber daya manusia selalu bertanggung jawab atas keberlangsungan suatu organisasi dalam suatu instansi. Salah satu tanggung jawab yang harus diperhatikan oleh pimpinan adalah memperhatikan kualitas kerja pegawai, khususnya optimalisasi komunikasi antara pimpinan dan bawahan dalam hal kepuasan kerja pegawai.

Semakin besar masalah pada suatu instansi maka semakin banyak pula jumlah pegawai yang dibutuhkan instansi tersebut, sehingga kemungkinan akan timbul masalah didalamnya. Seperti halnya dalam berkomunikasi, jika terjadi kendala dalam berinteraksi antara pimpinan dan bawahan akibat komunikasi yang kurang optimal, pekerjaan juga akan terhambat.

Komunikasi sangat penting dalam pengorganisasian. Karena tanpa adanya komunikasi maka pekerjaan tidak akan selesai secara maksimal dan dapat mempengaruhi kinerja di instansi tersebut. Oleh karena itu komunikasi sangat membantu dalam menyelesaikan suatu pekerjaan. Baik pimpinan maupun bawahan merasa puas dengan hasil kerja optimal mereka.

Wardhani (Wardani 2016) menyatakan bahwa komunikasi antara atasan dan bawahan memiliki pengaruh yang dominan terhadap kepuasan kerja, dengan komunikasi yang efektif akan tercipta hubungan yang baik antara atasan dan bawahan. Menurut Rivai (Rivai 2016) Komunikasi, adalah hubungan lisan maupun tulisan dua orang atau lebih yang dapat menimbulkan pemahaman dalam suatu rnasalah.

Dengan demikian dapat disimpulkan bahwasannya komunikasi 
sangat penting dalam suatu hubungan salah satunya adalah hubungan kerja dengan adanya komunikasi yang baik maka lingkungan kerja pun akan bisa dimengerti satu sama lain karena ada respon dalam penyampaian pesan-pesan.

Lingkungan kerja fisik, adalah keseluruhan atau keadaan berbentuk fisik yang ada di sekitar pekerja yang dapat mempengaruhi pekerja dalarn menjalankan tugas-tugas yang dibebankannya, misalnya: pewarnaan, kebersihan pertukaran udara, ruang gerak, keamanan dan kebisingan. Pengertian ini diungkapkan oleh Sedarmayanti (Serdarmayanti 2017) Lingkungan kerja non fisik adalah semua keadaan yang terjadi yang berkaitan dengan hubungan kerja baik hubungan dengan atasan maupun hubungan sesama rekan kerja, ataupun hubungan dengan bawahan.

Sedangkan Sedarmayanti (Sedarmayanti 2013)membagi lingkungan kerja menjadi dua bagian, yaitu: (a) lingkungan kerja fisik, dan (b) lingkungan kerja non fisik. Lingkungan kerja fisik adalah segala kondisi fisik yang ada disekitar tempat kerja yang dapat mempengaruhi karyawan baik secara langsung maupun tidak langsung. Lingkungan kerja fisik dapat dibagi menjadi dua kategori, yaitu: (1) Lingkungan yang berhubungan langsung dengan karyawan (seperti pusat kerja, kursi, meja dan sebagainya), (2) Lingkungan perantara atau lingkungan umum juga dapat disebut lingkungan kerja yang mempengaruhi kondisi manusia, misalnya: suhu, kelembaban, sirkulasi udara, penerangan, kebisingan, getaran mekanis, bau tidak sedap, warna, dan sebagainya. Untuk dapat meminimalisir pengaruh lingkungan fisik terhadap karyawan, langkah pertama yang dilakukan adalah mempelajari manusia, baik fisik maupun perilaku serta fisiknya, kemudian menggunakannya sebagai dasar untuk memikirkan lingkungan fisik yang sesuai. Lingkungan kerja non fisik adalah segala kondisi yang terjadi terkait dengan hubungan kerja, baik hubungan dengan atasan maupun hubungan dengan rekan kerja, maupun hubungan dengan bawahan.

Menurut Parlinda kondisi kerja adalah keadaan dimana tempat kerja yang baik meliputi lingkungan fisik dan lingkungan non fisik yang dapat memberikan kesan menyenangkan, aman, tentram dan lain sebagainya. Apabila kondisi kerja baik maka hal tersebut dapat memacu timbulnya rasa puas dalam diri karyawan yang pada akhirnya dapat memberikan pengaruh positif terhadap kinerja karyawan, begitu sebaliknya, apabila kondisi kerja buruk maka karyawan tidak akan mempunyai kepuasan dalam bekerja.

Kondisi lingkungan kerja yang nyaman akan mempengaruhi pegawai bekerja lebih giat dan menyelesaikan tugas-tugasnya sesuai jadwal. Keberhasilan peningkatan kinerja menuntut instansi mengetahui sasaran kinerja. Jika sasaran kinerja ditumbuhkan dari dalam diri karyawan akan membentuk suatu kekuatan diri dan jika situasi lingkungan kerja turut menunjang maka pencapaian kinerja akan lebih mudah, menurut Anwar Prabu Mangkunegara (Prabu Mangkunegara 2013)

Fenomena yang ada pada Dinas Tanaman Pangan Hortikultura Dan Peternakan Kabupaten Way Kanan dalam hal komunikasi adalah belum terjalinnya hubungan komunikasi yang baik antara atasan dan bawahan hal ini terlihat dari pegawai takut menyampaikan pendapat dan saran kepada atasan serta perintah yang diberikan oleh pimpinan tidak dapat 
ditangkap sesuai dengan yang diharapkan pimpinan karena pegawai menerima perintah tersebut dalam kondisi tegang.

\begin{tabular}{lccr}
\multicolumn{2}{c}{ Berdasarkan } & penelitian & awal, \\
wawancara & dengan & Kepala & Dinas \\
menunjukkan & adanya & kendala & dalam \\
komunikasi & antara & pimpinan & dan
\end{tabular}
bawahan, namun hal ini masih dapat ditangani dengan baik. Dari realitas contoh komunikasi yang terjadi diatas maka pimpinan memberikan contoh atau arahan agar dalam menyelesaikan pekerjaan tidak ada kesalahan. Antara pimpinan dan bawahan, mereka menjaga komunikasi yang baik agar baik pimpinan maupun bawahan dapat menikmati dan merasa nyaman dalam bekerja, padahal pekerjaan yang dibebankan adalah kerja keras dan memakan banyak pemikiran dan menguras tenaga. Belum terjalinnya hubungan komunikasi yang baik antara atasan dan bawahan, hal ini terlihat dari masih adanya pegawai yang takut menyampaikan pendapatan dan saran kepada atasan serta perintah yang diberikan pimpinan tidak dapat ditangkap seperti yang diharapkan oleh pimpinan karena yang diterima oleh pegawai urutan dalam kondisi tegang.

Kepuasan kerja dalam pekerjaan adalah kepuasan kerja yang dinikmati dalam pekerjaan dengan memperoleh pujian hasil kerja, penempatan, perlakuan, peralatan dan suasana lingkungan kerja yang baik.Pegawai yang lebih suka menikmati kepuasan kerja dalam pekerjaan ini akan lebih mengutamakan pekerjaannya dari balas jasa, walaupun balas jasa itu penting. Adanya kepuasan kerja tentunya mempengaruhi beberapa aspek yang melingkupi pada pegawai itu sendiri.

Kepuasan kerja adalah segala sesuatu yang menyangkut terpenuhinya kebutuhan baik secara moril maupun meteriil. Adapun indikator-indikator kepuasan kerja adalah apabila pangkat/golongan naik, pembayaran gaji tepat waktu, keakrapan antara pimpinan dengan bawahannya, penghargaan pimpinan terhadap bawahan, kerja sama, hubungan baik sesama rekan kerja, sarana dan prasarana yang memadai, disiplin, persaingan kerja yang sehat serta kesejahteraan apabila hal tersebut dapat terpenuhi Kepuasan kerja akan meningkat. Setiap Pegawai harus memiliki rasa puas terhadap pekerjaannya sebab dengan adanya rasa puas tersebut, maka hal ini mempengaruhi kerjanya.

Kepuasan kerja (Josiah 2011) merupakan sifat individu seseorang sehingga seseorang mempunyai tingkat kepuasan yang berbeda-beda sesuai dengan sistem nilai yang berlaku pada dirinya. Hal itu disebabkan oleh adanya perbedaan pada masing-masing individu yang terlibat dalam suatu organisasi.

Kepuasan kerja sendiri dapat diartikan sebagai sikap emosional yang menyenangkan dan mencintainya pekerjaannya dengan tolok ukur tingkat disiplin, moral kerja dan turnover. Menurut Robbins (Robbins 2017) Kepuasan kerja adalah sikap umum terhadap pekerjaan seseorang, yang menunjukkan perbedaan antara jumlah penghargaan yang diterima pekerja dan jumlah yang mereka yakini seharusnya mereka terima.

Kepuasan kerja berorientasi pada sikap individu pegawai terhadap tugasnya. Pegawai dengan tingkat kepuasan kerja yang tinggi memiliki sikap positif terhadap kewajibannya, sedangkan yang tidak puas akan memiliki sikap negatif terhadap kewajibannya. Pegawai memiliki tingkat kepuasan yang berbeda-beda 
terhadap sistem nilai yang berlaku. Penilaian yang tinggi terhadap aktivitas dan keinginan yang dirasakan oleh pegawai berdampak pada tingginya kepuasan yang diperoleh, sehingga kepuasan kerja merupakan penilaian yang menunjukkan adanya perasaan puas dalam bekerja.

Dari penjelasan di atas dapat disimpulkan bahwa kepuasan kerja adalah segala sesuatu yang menyangkut terpenuhinya kebutuhan baik secara moril maupun meteriil. Adapun indikatorindikator kepuasan kerja adalah apabila pangkat/ golongan naik, pembayaran gaji tepat waktu, keakrapan antara pimpinan dengan bawahannya, penghargaan pimpinan terhadap bawahan, kerja sama, hubungan baik sesama rekan kerja, sarana dan prasarana yang memadai, disiplin, persaingan kerja yang sehat serta kesejahteraan dapat terpenuhi apabila hal tersebut dapat terpenuhi motivasi kerja akan meningkat.

Hal tersebut di atas menunjukkan bahwa kepuasan kerja seseorang dipengaruhi oleh banyaknya faktor, tidak hanya gaji, tetapi terkait dengan pekerjaan itu sendiri, dengan faktor lain seperti hubungan dengan atasan, rekan sekerja, lingkungan kerja dan aturan-aturan. Selain itu hubungan komunikasi yang baik antara atasan dan bawahan belum terjalin dengan baik kondisi lingkungan kerja yang belum sepenuhnya baik sehingga semangat dan gairah kerja tidak optimal dan kepuasan kerja pegawai masih kurang.

Dalam hal kepuasan kerja pegawai kurang puas terhadap apa yang di capai dari target kegiatan yang di rencanakan antara lain, kebosanan atas rutinitas yang dialami dalam kegiatan tersebut karena kelelahan dan kurangnya komunikasi antara rekan kerja baik yang terstruktur maupun tidak terstruktur dalam hubungan koordinasi yang telah ditetapkan dalam pencapaian target kegiatan tersebut. Sering kali cara pimpinan langsung memberikan perintah atau arahan untuk menyelenggarakaan suatu kegiatan yang tidak sesuai dengan porsinya memberikan pengaruh terhadap pegawai dalam kepuasan kerja.

Berdasarkan penelitian sebelumnya oleh (Pareraway, Kojo, and Roring 2018) lingkungan kerja dan pelatihan tidak memiliki pengaruh terhadap kepuasan kerja, sedangkan secara parsial pemberdayaan memiliki pengaruh yang signifikan terhadap kepuasan kerja. Hal ini menunjukan lingkungan kerja berpengaruh kepada kepuasaan kerja.

Penelitian selanjutnya tentang komunikasi (Paramita, Lengkong, and Sendow 2016) berdasarkan hasil penelitian oleh bahwa komunikasi dan pelatihan tidak berpengaruh terhadap terhadap kepuasan kerja dan stress kerja tidak berpengaruh terhadap kepuasaan kerja.

Berdasarkan uraian diatas peneliti teratarik untuk melakukan penelitian dengan judul sebagai berikut: "Pengaruh Komunikasi dan Lingkungan Kerja terhadap Kepuasan Kerja Pegawai pada Kantor Dinas Tanaman Pangan Hortikultura Dan Peternakan Kabupaten Way Kanan".

\section{METODE PENELITIAN}

Penelitian ini bertujuan untuk menganalisis komunikasi dan lingkungan kerja terhadap kepuasaan kerja pada Dinas Dinas Tanaman Pangan Hortikultura Dan Peternakan Kabupaten Way Kanan. Jenis penelitian ini menggunakan penelitian kuantitatif deskriptif. Analis yang digunakan menggunakan regresi linear 
berganda Penelitian menggunakan 56 responden dan menggunakan jenis data primer dan skunder. Teknik pengumpulan data pada penelitian ini menggunakan observasi kuisioner dan telaah kepustakaan.

\section{HASIL DAN PEMBAHASAN}

Berdasarkan penelitian yang dilakukan diperoleh hasil sebagai berikut :

\section{Uji Validitas Data}

Uji validitas dilakukan dengan mengkirelasikan masing-masing dengan skor total variabel. Selanjutnya angka korelasi yang dihasilkan akan dibandingkan dengan nilai $r_{\text {tabel }}$ pada $\alpha=$ 0,05 yaitu sebesar 0.266 berdasarkan 56 responden (Sugiyono 2018)

Berdasarkan uji validitas, suatu item pertanyaan dikatakan valid apabila nilai $r_{\text {hitung }}$ skor item terhadap skor totalnya diatas 0.266, atau dikatakan tidak valid apabila nilai $\mathrm{r}_{\text {hitung }}$ item pertanyaan tersebut lebih kecil dari 0.266. Oleh karenanya, semakin baik nilai koefesien Korelasi Pearson suatu item, memperlihatkan semakin baik validitas item tersebut.

Pengujian dilakukan dengan menggunakan Program SPSS Versi 21. Berdasarkan pengujian validitas dari masing-masing variabel yaitu 10 pertanyaan utuk variabel Independent ( $\mathrm{X}_{1, X} \mathrm{X}_{2}$ ) dan variabel (Y) jawaban responden telah memiliki validitas yang cukup baik. Hasil keseluruhan dari pengujian validitas terhadap instrument pertanyaan untuk variabel Komunikasi $\left(\mathrm{X}_{1}\right)$ dan Lingkungan Kerja $\left(\mathrm{X}_{2}\right)$ serta variabel Kepuasan Kerja (Y) dapat dilihat pada Tabel 3 dibawah ini.
Tabel 3. Uji Validitas Komunikasi $\left(\mathrm{X}_{1}\right)$

\begin{tabular}{|c|c|c|c|}
\hline $\begin{array}{c}\text { Item } \\
\text { Pernyataan }\end{array}$ & $\mathbf{r}_{\text {tabel }}$ & $\begin{array}{c}\text { Koefesien } \\
\mathbf{r}_{\text {hitung }}\end{array}$ & Keterangan \\
\hline $\begin{array}{c}\text { Komunikasi } \\
\left(\mathbf{X}_{1}\right)\end{array}$ & 0.266 & 0,512 & Valid \\
\hline $\begin{array}{c}\text { Lingkungan } \\
\text { Kerja }\left(\mathrm{X}_{2}\right)\end{array}$ & 0.266 & 0,633 & Talid \\
\hline $\begin{array}{l}\text { Kepuasan } \\
\text { Kerja (Y) }\end{array}$ & 0.266 & 0,501 & Valid \\
\hline \multicolumn{4}{|c|}{ Sumber : data diolah, 2021} \\
\hline $\begin{array}{l}\text { Ber } \\
\text { validasi dia } \\
\text { dengan nil } \\
\text { dari r tab } \\
\text { dikatakan } \\
\text { lingkungan } \\
\text { valid. }\end{array}$ & $\begin{array}{r}\text { dik } \\
\text { rata } \\
\text { De } \\
\text { hwa } \\
\text { erja }\end{array}$ & $\begin{array}{l}\text { Tabel } \\
\text { hui bahw } \\
\text { ta } \mathrm{r} \text { hitung } \\
\text { an demi } \\
\text { variabel } \\
\text { lan kepu }\end{array}$ & $\begin{array}{l}\text { hasil uji } \\
\text { iilai } r \text { hitung } \\
\text { ebih besar } \\
\text { an dapat } \\
\text { munikasi, } \\
\text { aan kerja }\end{array}$ \\
\hline
\end{tabular}

\section{Uji Realibilitas Data}

Uji realibilitas digunakan untuk mengetahui layak tidaknya data responden yang digunakan dalam penelitian ini. Dapat dikatakan reliabel bila memiliki koefisien kehandalan reliabilitas sebesar 0,6 atau lebih (Uyanto 2016)

\section{Uji Reliabilitas Variabel Komunikasi $\left(\mathbf{X}_{1}\right)$}

Hasil dari uji reliabilitas variabel Komunikasi $\left(\mathrm{X}_{1}\right)$ berdasarkan data jawaban responden terhadap 10 pertanyaan seperti tertera pada. Dari hasil Uji Reliabilitas di atas di dapat nilai Alpha Komunikasi $\left(\mathrm{X}_{1}\right)$ sebesar 0,823, dan dapat disimpulkan bahwa kuesioner yang digunakan dalam penelitian ini dinyatakan reliabel karena alpha-nya sebesar $0,800>0,60$. Ini berarti bahwa alat ukur yang digunakan dalam penelitian ini sudah memiliki kemampuan untuk memberikan hasil pengukuran yang konsisten dalam mengukur gejala yang sama. 


\section{Analisis Kualitatif}

Dari hasil penelitian dapat disimpulkan bahwa Komunikasi, Lingkungan Kerja, dan Kepuasan Kerja dalam kondisi baik. Kecenderungan jawaban yang secara dominan menggambarkan kondisi yang baik ini tentunya bila semakin ditingkatkan akan mendorong pencapaian tujuan kepuasan kerja pegawai.

\section{Analisis Kuantitatif}

\section{Perhitungan Pengaruh antara Komunikasi $\left(\mathrm{X}_{1}\right)$ Terhadap Kepuasan Kerja (Y)}

Perhitungan pengaruh antara variabel Komunikasi $\left(\mathrm{X}_{1}\right)$ terhadap Kepuasan Kerja (Y) menggunakan hasil hitungan melalui Program SPSS versi 21, seperti tertera pada Tabel 1 :

Tabel 1

Perhitungan Tentang Korelasi Komunikasi $\left(\mathrm{X}_{1}\right)$ Lingkungan Kerja $\left(\mathrm{X}_{2}\right)$ terhadap Kepuasan Kerja (Y) dari 56 responden.

\begin{tabular}{|c|c|c|c|c|}
\hline \multicolumn{5}{|c|}{ Correlations } \\
\hline & & $\mathrm{x} 1$ & $x 2$ & $Y$ \\
\hline \multirow[t]{3}{*}{$\mathrm{x} 1$} & $\begin{array}{l}\text { Pearson } \\
\text { Correlation }\end{array}$ & 1 & ,632 & ,381* \\
\hline & $\begin{array}{l}\text { Sig. (2- } \\
\text { tailed) }\end{array}$ & & ,000 & ,020 \\
\hline & $\mathrm{N}$ & 56 & 56 & 56 \\
\hline \multirow[t]{3}{*}{$x 2$} & $\begin{array}{l}\text { Pearson } \\
\text { Correlation }\end{array}$ &, 632 & 1 &, $731^{* *}$ \\
\hline & $\begin{array}{l}\text { Sig. (2- } \\
\text { tailed) }\end{array}$ & ,000 & & ,000 \\
\hline & $\mathrm{N}$ & 56 & 56 & 56 \\
\hline \multirow[t]{3}{*}{$Y$} & $\begin{array}{l}\text { Pearson } \\
\text { Correlation }\end{array}$ & ,381 &, 731 & 1 \\
\hline & $\begin{array}{l}\text { Sig. (2- } \\
\text { tailed) }\end{array}$ & ,022 & ,000 & \\
\hline & $\mathrm{N}$ & 56 & 56 & 56 \\
\hline
\end{tabular}

Hasil perhitungan tingkat korelasi antar variabel Komunikasi $\left(\mathrm{X}_{1}\right)$ dengan Kepuasan Kerja (Y) sebesar 0,381. Jika dikonsultasikan dengan tabel Interpretasi
Koefesien Korelasi (Sugiyono : 2018) maka tingkat korelasi Komunikasi $\left(\mathrm{X}_{1}\right)$ dengan variabel Kepuasan Kerja (Y) dalam kategori korelasi “ rendah" yakni terletak diantara (0,200-0,399).

Koefisien Determinasi (KD) = $0.383 \times 100 \%=38,3 \%$. Dapat disimpulkan bahwa variabel Komunikasi $\left(\mathrm{X}_{1}\right)$ menjelaskan variasi perubahan terhadap variabel Kepuasan Kerja (Y) sebesar 38,3\%, sedangkan sisanya dijelaskan oleh faktor lain yang tidak dikaji dalam penelitian ini. Berdasarkan hasil penelitian maka diperoleh data pengaruh antara Komunikasi terhadap Kepuasan Kerja Pegawai.

\section{Uji t}

Berdasarkan hasil Uji t didapat nilai $\mathrm{t}$ hitung $=2,439$. Apabila dibandingkan dengan $t_{\text {tabel }}$ pada taraf signifikan yaitu 1,674 , maka $t_{\text {hitung }}=2,439>t_{\text {tabel }}=1,674$ sehingga dapat disimpulkan bahwa ; Ha yang menyatakan terdapat pengaruh antara variabel Komunikasi $\left(\mathrm{X}_{1}\right)$ terhadap variabel Kepuasan Kerja (Y) dapat diterima. Jadi variabel Komunikasi $\left(\mathrm{X}_{1}\right)$ berpengaruh terhadap variabel Kepuasan Kerja (Y).

Persamaan regresi antara variabel Komunikasi $\left(\mathrm{X}_{1}\right)$ terhadap variabel Kepuasan Kerja (Y) adalah Y $=33,519+$ $0,418 \mathrm{X}_{1}$, yang artinya setiap kenaikan satu point daripada variabel Komunikasi akan diikuti oleh naiknya variabel Kepuasan Kerja sebesar 0, 418 point.

\section{Perhitungan Pengaruh antara Lingkungan Kerja $\left(\mathbf{X}_{2}\right)$ Terhadap Kepuasan Kerja (Y)}

Hasil perhitungan tingkat korelasi antar variabel melalui Program SPSS versi 21 diperoleh besarnya tingkat korelasi antara variabel Lingkungan $\operatorname{Kerja}\left(\mathrm{X}_{2}\right)$ dengan Variabel Kepuasan Kerja (Y) adalah sebesar 0,731. Jika dikonsultasikan dengan tabel Interpretasi Koefesien 
Korelasi maka tingkat korelasi Lingkungan Kerja $\left(\mathrm{X}_{2}\right)$ dengan variabel Kepuasan Kerja (Y) termasuk dalam kategori korelasi "kuat" yakni terletak pada (0,600- 0,799). Berdasarkan hasil penelitian di atas, maka diperoleh Koefisien Determinasi $(\mathrm{KD})=0,464 \mathrm{x}$ $100 \%=46,4 \%$. Dapat disimpulkan bahwa variabel Lingkungan Kerja $\left(\mathrm{X}_{2}\right)$ menjelaskan variasi perubahan variabel Kepuasan Kerja (Y) sebesar 46,4\%, sedangkan sisanya dijelaskan oleh faktor lain yang tidak dikaji dalam penelitian ini. Berdasarkan hasil penelitian, diperoleh data pengaruh antara Lingkungan Kerja $\left(\mathrm{X}_{2}\right)$ terhadap Kepuasan Kerja (Y) hasil Uji t didapat nilai $t_{\text {hitung }}=6,530$. Apabila dibandingkan dengan $t_{\text {tabel }}$ pada taraf signifikan yaitu 1,674 , maka thitung $=6,530>\mathrm{t}_{\text {tabel }}=1,674$, sehingga dapat disimpulkan bahwa; Hipotesis yang menyatakan terdapat pengaruh antara variabel Lingkungan Kerja $\left(\mathrm{X}_{2}\right)$ terhadap Kepuasan Kerja (Y) dapat diterima. Jadi variabel Lingkungan Kerja $\left(\mathrm{X}_{2}\right)$ berpengaruh terhadap variabel Kepuasan Kerja (Y) pada Dinas Tanaman Pangan Hortikultura Dan Peternakan Kabupaten Way Kanan.

Persamaan regresi antara variabel Lingkungan Kerja $\left(\mathrm{X}_{2}\right) \quad$ terhadap Kepuasan Kerja (Y) adalah Y $=17,546+$ $0,625 \mathrm{X}_{2}$, yang artinya setiap kenaikan satu point dari variabel Lingkungan Kerja akan diikuti oleh variabel Kepuasan Kerja sebesar 0,625 point.

\section{Perhitungan Pengaruh antara} Komunikasi $\left(X_{1}\right)$ dan Lingkungan Kerja $\left(\mathbf{X}_{2}\right)$ Terhadap Kepuasan Kerja (Y)

Perhitungan simultan antara variabel Komunikasi $\left(\mathrm{X}_{1}\right)$ dan Lingkungan Kerja $\left(X_{2}\right)$ secara bersama-sama (simultan) terhadap variabel Kepuasan Kerja (Y) pada Dinas Tanaman Pangan Hortikultura Dan Peternakan Kabupaten
Way Kanan melalui hasil perhitungan bahwa korelasi Komunikasi dan Lingkungan Kerja dengan Kepuasan Kerja sebesar 0,755, artinya ketiga variabel tersebut mempunyai pengaruh yang kuat dan positif. Berarti semakin baik Komunikasi dan Lingkungan Kerja maka Kepuasan Kerja akan semakin meningkat, sebaliknya jika Komunikasi dan Lingkungan Kerja tidak baik maka Kepuasan Kerja pada Dinas Tanaman Pangan Hortikultura Dan Peternakan Kabupaten Way Kanan akan menurun.

Koefisien Determinasi $(\mathrm{KD})=$ $0,671 \times 100 \%=67,1 \%$. Jadi dapat ditarik kesimpulan bahwa besarnya pengaruh antara Komunikasi dan Lingkungan Kerja terhadap Kepuasan Kerja sebesar 67,1\% dan sisanya sebesar $32,9 \%$ akibat penyesuaian faktor lain yang tidak penulis teliti dalam penelitian ini.

\section{Analisis Regresi Linier antara Komunikasi $\left(\mathrm{X}_{1}\right)$ dan Lingkungan Kerja $\left(\mathbf{X}_{2}\right)$ Terhadap Kepuasan Kerja (Y)}

Berdasarkan hasil penelitian, diperoleh data perhitungan regresi ganda antara Komunikasi $\left(\mathrm{X}_{1}\right)$ dan Lingkungan Kerja $\left(\mathrm{X}_{2}\right)$ terhadap Kepuasan Kerja (Y),seperti tertera pada Tabel 
Tabel 2

Perhitungan Regresi Ganda Antara

Komunikasi, Lingkungan Kerja dan Kepuasan Kerja Pegawai.

\begin{tabular}{|c|c|c|c|c|c|c|}
\hline \multicolumn{7}{|c|}{ Coefficients $^{a}$} \\
\hline \multirow{2}{*}{\multicolumn{2}{|c|}{ Model }} & \multicolumn{2}{|c|}{$\begin{array}{l}\text { Unstandardiz } \\
\text { ed } \\
\text { Coefficients }\end{array}$} & $\begin{array}{l}\text { Stand } \\
\text { ardize } \\
\text { d }\end{array}$ & $\mathrm{T}$ & $\begin{array}{l}\text { Si } \\
\text { g. }\end{array}$ \\
\hline & & B & $\begin{array}{l}\text { Std. } \\
\text { Error }\end{array}$ & Beta & & \\
\hline \multirow[t]{3}{*}{1} & $\begin{array}{l}\text { (Co } \\
\text { nst } \\
\text { ant) }\end{array}$ & $\begin{array}{r}18 \\
21 \\
6\end{array}$ & 4,982 & & $\begin{array}{r}3 \\
8 \\
1 \\
7\end{array}$ & $\begin{array}{l}, 0 \\
01\end{array}$ \\
\hline & $\mathrm{x} 1$ & $\begin{array}{r}, 28 \\
5\end{array}$ & ,119 & , 105 & $\begin{array}{l}7 \\
1 \\
7\end{array}$ & $\begin{array}{r}4 \\
79\end{array}$ \\
\hline & $x 2$ & $\begin{array}{r}68 \\
7\end{array}$ & , 141 & 814 & $\begin{array}{r}5 \\
5 \\
8 \\
1\end{array}$ & $\begin{array}{l}\text {,0 } \\
00\end{array}$ \\
\hline \multicolumn{7}{|c|}{ a. Dependent Variable: y } \\
\hline
\end{tabular}

Didasarkan tabel di atas, selanjutnya dimasukkan persamaan :

$$
Y=18,216+0,285 X_{1}+0,687 X_{2}
$$

1. Setiap terjadi peningkatan nilai pada variabel Komunikasi sebesar satu point, maka Kepuasan Kerja akan meningkat sebesar 0,285 point.

2. Setiap terjadi peningkatan nilai pada variabel Lingkungan Kerja sebesar satu point, maka Kepuasan Kerja akan meningkat sebesar 0,687 point.

Berdasarkan keterangan di atas dapat ditarik kesimpulan bahwa nilai koefisien regresi $X_{1}=0,285$ lebih kecil daripada koefisien regresi $X_{2}=0,687$. Hal ini menunjukkan bahwa pengaruh antara variabel Komunikasi lebih kecil atau Lingkungan Kerja lebih dominan dibandingkan Komunikasi dalam meningkatkan Kepuasan Kerja Pegawai.

\section{Uji Hipotesis Simultan}

Hasil uji hipotesis secara simultan tertera pada Tabel dibawah ini :

Tabel 3

Hasil Uji Hipotesis secara Simultan

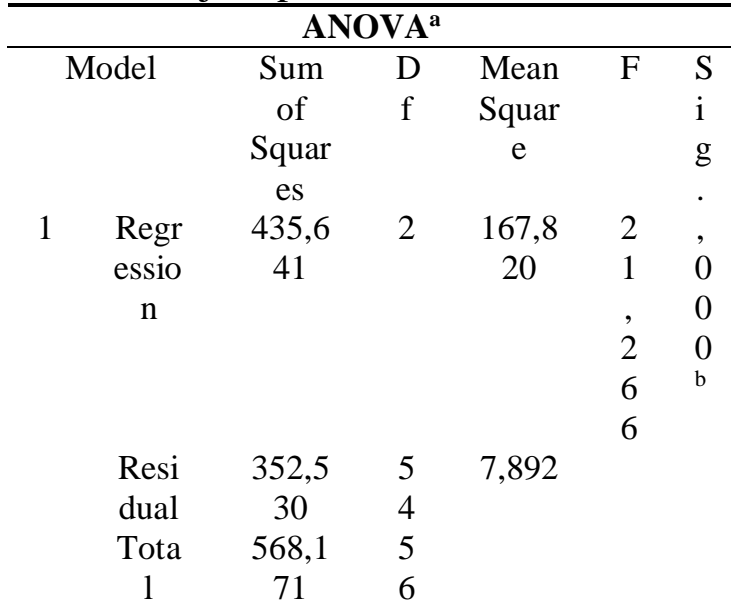

a. Dependent Variable: y

b. Predictors: (Constant), x2, x1

Dari uji anova atau $\mathrm{F}$ test didapat $\mathrm{F}$ hitung sebesar 21,266 dengan tingkat signifikan 0,000 karena probability jauh lebih kecil dari 0,05 , kemudian nilai $\mathrm{F}$ tabel 3,175, ini berarti $\mathrm{F}$ hitung $>\mathrm{F}$ tabel maka Komunikasi $\left(\mathrm{X}_{1}\right)$ dan Lingkungan Kerja $\left(\mathrm{X}_{2}\right)$ secara bersama-sama (simultan) berpengaruh terhadap Kepuasan Kerja (Y) pada Dinas Tanaman Pangan Hortikultura Dan Peternakan Kabupaten Way Kanan. Dengan demikian maka hipotesis yang menyatakan Terdapat pengaruh antara Komunikasi $\left(\mathrm{X}_{1}\right)$ dan Lingkungan Kerja $\left(\mathrm{X}_{2}\right)$ secara bersamasama terhadap Kepuasan Kerja (Y) pada Dinas Tanaman Pangan Hortikultura Dan Peternakan Kabupaten Way Kanan adalah dapat terbukti atau diterima berdasarkan hasil analisis yang dilakukan di atas.

\section{Pembahasan}

\section{Pengaruh Komunikasi Terhadap Kepuasan Kerja Pegawai}

Dari hasil penelitian dinyatakan bahwa Komunikasi pada Dinas Tanaman 
Pangan Hortikultura Dan Peternakan Kabupaten Way Kanan dalam kategori baik. Hasil perhitungan tingkat korelasi antara variabel Komunikasi $\left(\mathrm{X}_{1}\right)$ dengan Kepuasan Kerja (Y) sebesar 0,381 termasuk dalam kategori rendah yakni $(0,200$ - 0,399). Besarnya koefisien Determinasi antara Komunikasi terhadap Kepuasan Kerja adalah $=38,3 \%$. Uji hipotesis parsial melalui uji $\mathrm{t}$ (test) diperoleh nilai thitung antara Komunikasiterhadap Kepuasan Kerjasebesar $=2,439$ dan $t_{\text {hitung }}$ 2,439> $t_{\text {tabel }}$ 1,674. Persamaan regresi antara Komunikasi dan Kepuasan Kerja adalah sebesar $\mathrm{Y}=33,519+0,418 \mathrm{X}_{1}$, yang menunjukkan setiap kenaikan satu point dari variabel Komunikasi akan diikuti oleh naiknya variabel Kepuasan Kerja pada Dinas Tanaman Pangan Hortikultura Dan Peternakan Kabupaten Way Kanan sebesar $=0,418$ point

\section{Pengaruh Lingkungan Kerja Terhadap Kepuasan Kerja Pegawai}

Hasil penelitian menunjukkan bahwa Lingkungan Kerja $\left(\mathrm{X}_{2}\right)$ pegawai pada Dinas Tanaman Pangan Hortikultura Dan Peternakan Kabupaten Way Kanan dalam kategori baik. Hasil perhitungan tingkat korelasi antara variabel Lingkungan Kerja $\left(\mathrm{X}_{2}\right)$ dan variabel Kepuasan Kerja (Y) pada Dinas Tanaman Pangan Hortikultura Dan Peternakan Kabupaten Way Kanan adalah sebesar 0,731, termasuk dalam kategori sedang yakni $(0,600-0,799)$. Besarnya Koefisien Determinasi antara Lingkungan Kerja $\left(\mathrm{X}_{2}\right)$ terhadap Kepuasan Kerja (Y) adalah $46,4 \%$. Uji hipotesis parsial melalui uji $\mathrm{t}$ (test) diperoleh nilai thitung antara Lingkungan Kerja terhadap Kepuasan Kerja sebesar $=6,530$ dan thitung 6,530 > $t_{\text {tabel }}$ 1,674. Persamaan regresi antara Lingkungan Kerja dengan Kepuasan Kerja adalah sebesar $\mathrm{Y}=17,546+0,625 \mathrm{X}_{2}$, yang menunjukkan setiap kenaikan satu point dari variabel Lingkungan Kerja akan diikuti oleh naiknya variabel Kepuasan Kerja pada Dinas Tanaman Pangan Hortikultura Dan Peternakan Kabupaten Way Kanan sebesar 0,625 point. Hal ini menunjukkan bahwa Lingkungan Kerja berpengaruh dalam meningkatkan Kepuasan Kerja Pegawaii.

Hal ini sejalan dengan penelitian sejalan dengan penelitian oleh(Aruan and Fakhri 2015) menujukan bahwa lingkungan fisik maupun non fisik berpengaruh signifikan terhadap kepuasaan kerja pegawai.

\section{Pengaruh Komunikasi dan Lingkungan Kerja Secara Simultan Terhadap Kepuasan Kerja Pegawai}

Seperti yang telah dijelaskan uji parsial (Uji t), pengaruh Komunikasi $\left(X_{1}\right)$ dan Lingkungan Kerja $\left(\mathrm{X}_{2}\right)$ terhadap Kepuasan Kerja (Y) diperoleh thitung variabel Komunikasi 2,439>t tabel 1,674 dengan signifikasi $0,002<0,05$. Selanjutnya hasil penghitungan koefisien regresi dengan uji thitung variabel Lingkungan Kerja 6,530 $>t_{\text {tabel }} 1,674$ dengan signifikasi $0,000<0,05$. Sedangkan hasil uji simultan (uji f) diperoleh $F_{\text {hitung }}$ dari hasil regresi sebesar 21,266 > $F_{\text {tabel }}$ 3,276 dengan signifikasi $0,000<0,05$ sesuai dengan teori pengambilan keputusan jika nilai sig < 0,005 dan thitung $>t_{\text {tabel }}$ maka Ho ditolak atau Ha diterima.

Nilai koefisien determinasi $\left(\mathrm{R}^{2}\right)$ sebesar 0,671 berarti bahwa variabel bebas yaitu variabel Komunikasi $\left(\mathrm{X}_{1}\right)$ dan Lingkungan Kerja $\left(\mathrm{X}_{2}\right)$ secara simultan dapat meningkatkan variabel terikat yaitu variabel Kepuasan Kerja (Y) sebesar 67,1 $\%$ dan sisanya $32,9 \%$ tidak penulis teliti dalam penelitian ini. 


\section{SIMPULAN}

Berdasarkan analisis hasil penelitian dan pembahasan tentang komunikasi dan lingkungan kerja terhadap kepuasan kerja pegawai maka dapat disimpulkan bahwa komunikasi dan lingkungan kerja berpengaruh terhadap kepuasaan kerja pegawai pada Dinas Tanaman Pangan Hortikultura Dan Peternakan Kabupaten Way Kanan, dibuktikan dengan hipotesis yang menyatakan bahwa komunikasi dan lingkungan kerja berpengaruh terhadap kepuasan kerja pegawai sebesar 67,1\% oleh komunikasi dan lingkungan kerja secara bersama-sama, sementara sisanya sebesar 32,9 \% dipengaruhi oleh faktor yang lainnya yang tidak ada dalam penelitian ini.

\section{DAFTAR PUSTAKA}

Aruan, Quinerita Stevani, and Mahendra Fakhri. 2015. "PENGARUH LINGKUNGAN KERJA TERHADAP KEPUASAN KERJA KARYAWAN LAPANGAN DEPARTEMEN GRASBERG POWER DISTRIBUTION PT. FREEPORT INDONESIA.” 27:22.

Josiah, Trisnowati. 2011. "Pengaruh Budaya Organisasi, Komitmen Dan Kepuasan Kerja Terhadap Kinerja Pegawai Di Provinsi Lampung." Jurnal Manajemen Dan Bisnis Vol.2 2(1):16-29.

Paramita, L., V. P. K. Lengkong, and G. M. Sendow. 2016. "PENGARUH KOMUNIKASI ORGANISASI DAN STRES KERJA TERHADAP KEPUASAN
KERJA SERTA DAMPAKNYA TERHADAP KINERJA

KARYAWAN DI

PERUSAHAAN UMUM BULOG DIVISI REGIONAL SULAWESI UTARA.” 12.

Pareraway, A. S., C. Kojo, and F. Roring. 2018. "PENGARUH LINGKUNGAN KERJA, PELATIHAN, DAN PEMBERDAYAAN SDM TERHADAP KEPUASAN KERJA KARYAWAN PT. PLN (PERSERO) WILAYAH SULUTTENGGO.” 10.

Prabu Mangkunegara, Anwar. 2013. Manajemen Sumber Daya Manusia Perusahaan. Bandung: Remaja Rosdakarya.

Rivai. 2016. Pengertian Komunikasi. Jakarta: PT Gramedia Pustaka.

Robbins, Stephen P. 2017. 2017. Perilaku Organisasi, Jilid 2, , Jakarta. Jakarta: PT. Indeks Kelompok Gramedia.

Sedarmayanti. 2013. . . 2013. Sumber Daya Manusia Dan Produktivitas Kerja. Bandung: Mandar Maju. Bandung: Mandar Maju.

Serdarmayanti. 2017. Manejeman Sumber Daya Manusia. Jakarta: Refika Aditama.

Siagian, Sondang P. 2014. Manajemen Sumber Daya Manusia. Jakarta: Bumi Aksara.

Sugiyono. 2018. Metode Penelitian Kombinasi (Mixed Methods). Bandung: CV Alphabeta. 
Nuraeni : Analisis Komunikasi dan Lingkungan Kerja Terhadap Kepuasaan Kerja Pegawai Pada Dinas Tanaman Pangan Hortikultura Dan Peternakan Kabupaten Way Kanan

Uyanto. 2016. Metode Statistik Penelitian.

Jakarta: Ghalia Indonesia.

Jakarta: Ghalia Indonesia.

Wardani. 2016. Pengertian Komunikasi.

Yogyakarta: Liberty. 